\title{
THE INFLUENCE OF CUSTOMER VALUE AND SELF CONGRUITY ON EMOTIONAL BRAND ATTACHMENT
}

\author{
*Aysel ERCIS \\ **Tuğba YILDIZ \\ ****Bahar TURK \\ "Atatürk University, Turkey \\ ** Bayburt University, Turkey \\ ***Ondokuz Mayls University, Turkey
}

\begin{abstract}
The place and importance of the concept of brand attachment in marketing strategies gradually increase. The most important reason for it is the tough competition in the markets due to abundance of goods and services. Thus, firms try to ensure sustainability by embarking on a quest of new strategic weapons which shall contribute to the brand attachment. For this purpose, the influence of customer value, brand trust, and self congruity on the emotions known to have effect on attachment today has been researched. Also, it has been tested whether the emotional brand attachment has influence on the positive word of mouth and willingness to pay premium price. In this context, survey study has been conducted on the students who study at the central campus of Atatürk University. As the result of the analyses applied on the data collected, it has been observed that social value and emotional value among the contexts of brand trust, self congruity, and customer value are influential on the emotional brand attachment; however, functional value has no significant influence. On the other hand, it has been detected that emotional brand attachment has significant influence on the willingness to pay premium price and positive word of mouth.
\end{abstract}

Keywords: Emotional Brand Attachment, Customer Value, Self Congruity

\section{INTRODUCTION}

The products which gradually resemble to each other more in terms of performance in today's markets have increased the importance of emotional differences and brand attachment to be created (Pawle and Cooper, 2006: 38). Thus, the firms have tended towards emotional elements in order to influence customers more and to become preferred brand in long-term (Hung, 2014). The reason of using this concept as strategic variable in creating attachment is that it is known that the decisions of individuals are formed not only with logic but also emotions. Customer behaviors arising mostly emotionally and intuitively are the indicator for it (Pawle and Cooper, 2006).

Emotional benefits of the brands influence the attitude and beliefs of customers to the brand. Thus, it is of importance to present emotional benefits which are in congruity with the expectations and desires of customers (Ruth, 2001). In this mutually-fed relationship, increase in the emotional attachment of the customers to the brand also affects the power of the brand (Abosag et al., 2012). In other words, customer showing high emotional attachment to the brand shall adore the brand, devote him/herself to it, even love it, and become the defender of the brand against anything and anyone (Hemetsberger et al., 2009: 430).

In addition to it, there are many studies dealing with the relationship between product, brand, and services and emotional attachment. For instance, Wu et al. (2017) have examined the influences of self congruity, design aesthetic, and instant mobile messaging identification on the emotional attachment. As the result of this study, it has been found that self congruity, design aesthetic, and instant mobile messaging identification have positive influences on the emotional attachment. Abdullah et al. (2015) have researched the effects of the total experience on emotional attachment and they have concluded that the total experience has significantly positive effect on emotional attachment. Barreda et al. (2013) have researched the effect of the assessment of brand on the emotional brand attachment and stated that the assessment of the brand has a positive effect on emotional attachment. Burke and Stetse (1999) have examined the relationship between trust and emotional attachment in the study which they have conducted. According to the conclusions which they have obtained, emotional attachment increases as 
long as trust does so. Theng So et al. (2013) have researched the effect of the corporate values on the emotional attachment and stated that the more positive the customers perceive corporate values, the greater the emotional attachment shall be. Ishikawa (2013) has investigated the effects of self-congruity and brand experience on emotional brand attachment. In the study, he has found that ideal self-congruity, social self-congruity, and brand experience had positive effects on emotional attachment. In direction of support of the related literature, customer value, brand trust, and self congruity have been discussed as variables affecting the emotional brand attachment and it has been aimed to contribute the article by researching the influence of the emotional brand attachment on the positive word of mouth and willingness to pay premium price.

In the first part of this study, which consists of two parts, the literature about research variables has been searched. In the second part, the findings, comments, and recommendations obtained as a result of the questionnaire study applied to the students at the center campus of Atatürk University are given.

\section{LITERATURE REVIEW AND THEORETICAL FRAMEWORK}

\section{Customer Value}

It is compulsory for companies aiming to maintain their sustainability to take into account their customers. This is because products and services that provide customer value are successful on the market (Cepeda-Carrion et al., 2016: 3). There are different types of customer values that can be offered to consumers. Kim et al. (2009) have defined customer value types as emotional value, social value and functional value. Emotional value expresses the benefit as the result of emotional state of a product. Social value means the benefit as the result of the product's ability to develop social self-perception and functional value is the result obtained by reducing the perceived cost of the product in the short and long run (related to the price), as well as the expected performance and the quality obtained from the perceived quality (qualitative) (Sweeney and Soutar, 2001). Again, according to Kim et al. (2011), emotional value includes aesthetics and entertainment, and emotional value is the 'benefit of trying new or different things'. The emotional value to the brand is related to the positive emotions that follow the use of the brand. Thanks to this value, consumers' brand loyalty increases.(Asshidin et al., 2016: 641).

In the process of creating customer value, it was thought that it would be enough to create congruity between product price and quality at the beginning, but recent studies have shown that variables such as brand confidence and self-congruity are also influential factors for creating good customer value (Lin et al., 2009: 1184). In this context, brands that create value are expressed as brands that establish emotional bonds with consumers and reflect their core values (Berry, 2000: 134). Consumers who are affected by the positive values of the brands and whose expectations are met are transformed into customers who are strongly committed (Aydeniz and Yüksel, 2007: 107). In addition, emotional, social, and functional values that individuals acquire from brands influence the willingness of individuals to buy and willingness to pay premium price (Hur et al., 2012; Li et al., 2013) and offer firms the opportunity to gain competitive advantage (Martelo Landroguez et al., 2011). It is generally accepted that there is a very close rational link between values and emotions (Oliver-Skuse, 2015). Todd (2014) stated that there is a relationship between emotion and value. In addition, advocates of Cognitive Theory have stated that emotions are a form of belief or value judgment.

\section{Brand Trust}

Brand trust is the security that consumers feel when interacting with the brand. This is based on the perception that the brand is responsible for the welfare and interests of the consumer (Delgado-Ballester et al., 2003: 11). Chaudhuri and Holbrook (2001: 82) have defined brand trust as the desire of the average consumer to rely on the brand's ability to perform the specified function.

Several studies have revealed that trust and satisfaction variables are influential in the formation of emotional attachment to the brand. Chinomona (2016) has emphasized in studies that there is a strong relationship between brand loyalty and brand trust and Levy and Hino (2016) have point out that customers have a positive relationship between brand trust and emotional attachment. Vlachos et al. (2010) have found in the research which they have conducted for the retail firms that customer trust has an important influence on the emotional attachment. The findings also show that consumers are directed to the brand they are satisfied with in repetitive purchases and emotional loyalty is formed by the strengthening of the relationship (Sağlam and Sağlam, 2016: 36). In order to create brand attachment in 
the consumer, marketers invest in strategies that enhance brand satisfaction and brand trust. It is also known that there is a positive relationship between brand attachment and trust (Chinomona, 2013).

\section{Self Congruity}

Self- congruity is the one between consumer's brand image and self-perception (Sirgy and Johar, 1999). Sirgy et al. (2000) have stated that there are four types of self-congruity. These are actual self-congruity, ideal self- congruity, social self-congruity, and ideal social self-congruity. While actual self-congruity reflects how an individual sees himself, ideal self-congruity expresses how he/she wants to be. The social self is how the other person sees the individual, and the ideal social self is how the individual wants to be seen/perceived by other people.

It has been found in researches on different sample groups in different categories in terms of literature that high self- congruity in young consumers increases the emotional brand attachment (Hwang and Kandampully, 2012), self-congruity has positive influence on emotional brand attachment (Yusof and Ariffin, 2016), self-congruity has positive influence on the loyalty to the store (Das, 2014), brand selfcongruity has an significant influence on the emotional brad attachment in luxury brands (Kim and Joung, 2016), and ideal self- congruity has considerable influence on the emotional attachment to the product (Park and Yoo, 2016). In addition, it is observed that consumers' self-image is highly compatible with the brand they prefer (Sirgy, 1982). The brand-self relationship is an essential component of attachment; because the center of the definition of brand attachment is the bond between the individual and the brand (Park et al, 2010). Nowadays, emotional brand attachment is one of the basic functions of marketing. One way to achieve this is to harmony between the personality of the brand and the consumer's self (Malär et al., 2011). Park et al., (2010) explain the relationship between self-connection and brand attachment by self-expansion theory. "Self-expansion theory emphasizes the dynamic character of close relationships and allows for predictions of changes in motivations and emotions as the relationship matures. Thus,selfexpansion theory promises a richer understanding of brand relationships at various points of the brand lifecycle" (Reimann et al., 2012: 129).

\section{Emotional Attachment}

Emotion is a psychological readiness that develops based on one's own thoughts and evaluations of events. Emotions are at the center of the actions of the individuals (Bagozzi et al., 1999). When we look at the relationship between brands and emotions, it can be said that positive emotions influence brand loyalty positively (Lee et al., 2009). It is known that consumers are desirous of having and possessing the brands associated with their lifestyles and their passions (Jawahar and Maheswari, 2009: 9).

Research also suggests that there is a positive relationship between the level of emotional attachment to the brand and willingness to pay premium price (Jiménez and Voss, 2014). Assiouras et al. (2015) found a positive relationship between brand attachment and willing to pay more, while Vlachos et al. (2010) pointed out that emotional attachment of the customers has influence on the positive word of mouth. Heath et al. (2006), on the other hand, emphasized in the study of advertising which they conducted that the emotional content of the advertisement should be at a high level if the intent of the advertisement is to establish strong relationships between the brand and the consumer.

\section{Positive Word of Mouth}

Word of mouth marketing is an important information source for the consumers. Today, many consumers talk about their preferred brand, promote it, influence the attitudes and behaviors of other consumers (Sicilia et al., 2016). Word of mouth marketing, which helps to promote products or services without paying for promotions and advertisements, can be positive or negative (Lien and Cao, 2014: 106). In this way, marketers who support positive word of mouth try to promote their products to their customers.

There are many elements which affect oral communication. Satisfaction is one of these elements. Customers who are satisfied with the brand/product are involved in positive oral communication (Naylor and Kleiser, 2000: 27), while emotional attachment to the brand is also increasing. Hudson et al. (2015) emphasize that customers participate in more word of mouth marketing activities as their emotional attachment increases. Similarly, Abubakar and Mavondo (2014) point out that emotional experiences have a positive influence on positive word of mouth. The effect of emotional brand attachment on word of mouth is related to attachment theory (Vlachos et al., 2010). "Attachment theory addresses an 

impressive array of research questions concerning the functions, emotional dynamics, evolutionary origins, and developmental pathways of human affectional bond'(Hazan and Shaver, 1994:1).

\section{Willingness to Pay Premium Price}

Willingness to pay premium price that provides sustainable competitive advantage and greater profitability is of great importance to companies (Casidy and Wymer, 2016: 190). Aaker (1996: 106) expresses the importance of a customer's willingness to pay a premium price for a brand that 'the main indicator of loyalty is the amount that a client will pay for a brand as a result of comparison between brands that offer similar benefits to their customers'.

One of the most important factors for willingness to pay premium price is the generation of emotional brand attachment. The studies conducted reveal that emotional attachment is a significant positive effect on premium price payment (Thomson et al., 2005; Orth et al., 2010). But what should not be avoided here is that the upper limit of the price which the consumers shall be willing to pay may vary. For this reason, it is imperative that brands create value at a level that answer for the price consumers are content to pay and are aware of the label price they determine. It is also necessary to underline that companies that have succeeded in developing appropriate strategies for the value of their brand shall succeed in increasing sales volume and profit margins by transforming consumers into volunteers (Thanasuta and Metharom, 2015: 200). Thomson et al., (2005) who investigated the effect of emotional brand attachment on premium price payment, has associated the hypothesis with attachment theory.

\section{METHODOLOGY}

\section{Purpose, Scope and Limitations of the Study}

Firms try to persuade consumers and create brand attachment by using many different methods for their own brands to be preferred. Therefore, identifying variables that affect the emotional elements that appear to be at the center of the behavior of individuals is crucial to creating loyal customers to the brand. In this respect, the aim of the research is to investigate the influence of customer value, brand trust, and selfcongruity on the emotional attachment to the brand that individuals choose on sports shoes. On the other hand, influence of emotional brand attachment on the willingness to pay premium price and positive word of mouth has been examined in the study.

The research has been conducted on the students who stated that they use sport shoes and generally prefer a certain brand with an age of 18 and over in Erzurum central district with a face-to-face survey method. The results are valid for this sample and cannot be generalized for other product groups, brands, and cities.

\section{Research Model and Hypotheses}

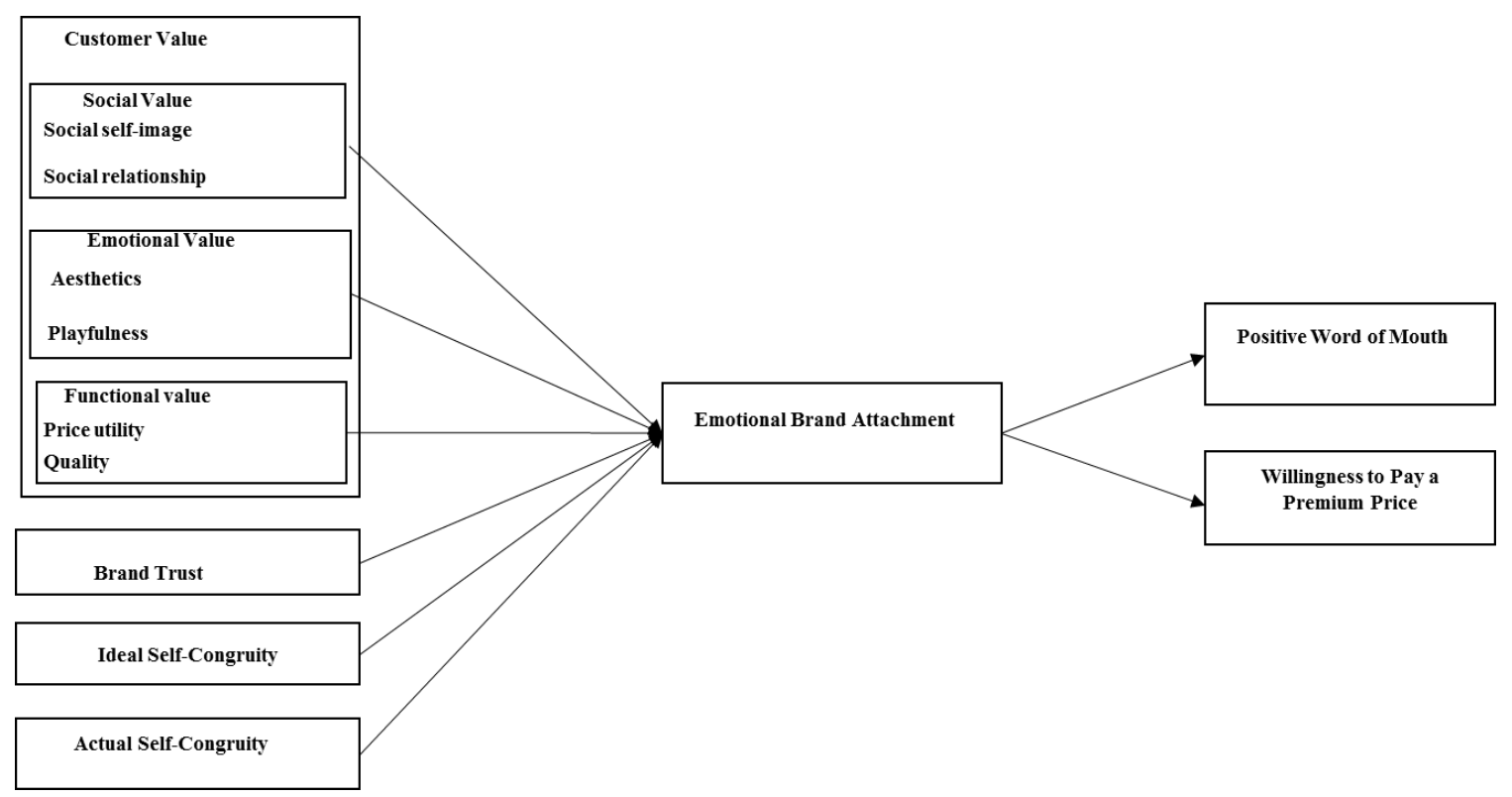

Figure 1. Research Model 
Journal of Global Strategic Management | V. 12 | N. 2 | 2018-December| isma.info | 075-086 | DOI: 10.20460/JGSM.2019.270 The hypotheses determined in line with the aim and model of the research are as follows:

H1: Customer value has significant influence on emotional brand attachment.

H1a: Social value has significant influence on emotional brand attachment.

H1b: Emotional value has significant influence on emotional brand attachment.

H1c: Functional value has significant influence on emotional brand attachment.

H2: Brand trust has significant influence on emotional brand attachment.

H3: Ideal self-congruity has significant influence on emotional brand attachment.

H4: Actual self-congruity has significant influence on emotional brand attachment.

H5: Emotional brand attachment has a significant effect on positive word of mouth.

H6: Emotional brand attachment has significant influence on the willingness to pay premium price.

\section{Data Collection Method and Process}

The target population of the research has been students studying at Atatürk University. On the other hand, in the research, since emotional brand attachment and the variables affecting this attachment have been investigated, sports shoes which are social consumption products have been preferred.

Prior to the final application of the questionnaire, pilot scheme was carried out with 20 students representing the research sample. Participants were asked to evaluate the clarity of the scales included in the questionnaire and the final form was given to the questionnaire by eliminating the identified deficiencies. Then, data were collected from 225 students who study at the central campus of Erzurum Atatürk University and wear sports shoes by face-to-face survey between 10 February and 10 March 2017 with convenience sampling method.

Among the scales used in formation of the survey, expressions related the customer value were adopted from Kim et al. (2009), expressions related to brand trust were adopted from Chinomona (2016), and expressions related to self-congruity, emotional brand attachment, positive word of mouth, and willingness to pay premium price were adopted from Ishikawa (2013), they were translated into Turkish, and these expressions were controlled with the method of back translation. In the analysis of the data, SPSS 20.0 and AMOS 20 packaged statistical software programs were used and descriptive statistics, confirmatory factor analysis, and structural equation analysis were applied to the data.

\section{Analysis of the Data}

According to the demographic characteristics of the sample, it was seen that the participants were mostly male $(54.2 \%)$ in 21-26 (62.2\%) age group with monthly incomes of $901 \mathrm{TL}$ and above $(46.2 \%)$.

Confirmatory factor analysis was conducted to test the fitness of the scales used in the research. The model fit values recommended by Çokluk et al. (2010) were based on the evaluation of whether or not the model fit values obtained as the result of the analysis are acceptable.

Table 1. Model Fit Values

\begin{tabular}{|l|l|l|l|l|l|l|l|}
\hline & Cronbach Alpha $(\boldsymbol{\alpha})$ & $\mathbf{X}^{2} / \mathbf{s d}$ & RMSEA & GFI & NFI & CFI & AGFI \\
\hline Customer Value & 0.76 & 1.88 & 0.06 & 0.85 & 0.88 & 0.94 & 0.81 \\
\hline Brand Trust & 0.92 & 1.44 & 0.04 & 1.00 & 1.00 & 1.00 & 0.97 \\
\hline Self Congruity & 0.81 & 2.14 & 0.07 & 0.95 & 0.97 & 0.98 & 0.90 \\
\hline Emotional Brand Attachment & 0.91 & 1.34 & 0.04 & 0.99 & 1.00 & 1.00 & 0.97 \\
\hline Positive Word of Mouth & 0.91 & 1.47 & 0.05 & 0.99 & 0.99 & 1.00 & 0.97 \\
\hline Willingness to Pay Premium Price & 0.94 & 1.03 & 0.01 & 1.00 & 1.00 & 1.00 & 0.98 \\
\hline
\end{tabular}


The structural model obtained in structural equation analysis performed as a whole to test the proposed research model after confirmatory factor analysis is as shown below.

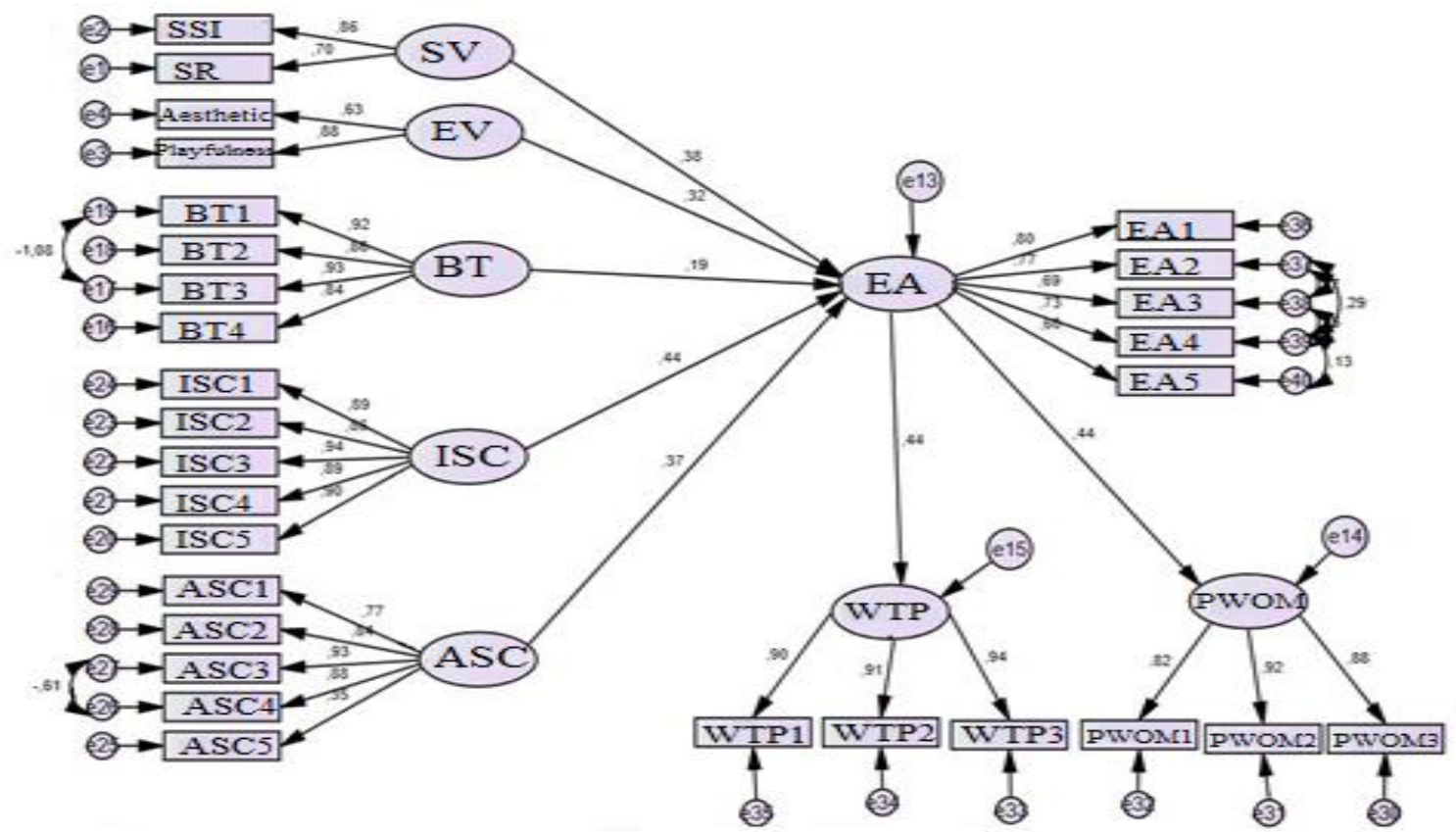

Figure 2. Structural Model

Key: SV: Social Value, SSI: Social Self-image, SR: Social Relationship, BT: Brand Trust, ISC: Ideal Self-Congruity, ASC: Actual Self-Congruity, EA: Emotional Attachment, WTP: Willingness to Pay Premium Price, PWOM: Positive Word of Mouth

This variable has been eliminated from the model because the statistical coefficients of the functional value variable within the customer value context are not meaningful. Model fit values obtained after the modification: It has been found that $\mathrm{X}^{2} / \mathrm{sd}=2.79, \mathrm{RMSEA}=0.09$, GFI $=0.78, \mathrm{NFI}=0.85, \mathrm{CFI}=0.90$, $\mathrm{AGFI}=0.72$.

Table 2. Structural Model Standardized Path Coefficients of Research Model

\begin{tabular}{|l|c|c|c|}
\hline Statistically Important Paths & $\begin{array}{l}(\mathbf{t}) \\
\text { Value }\end{array}$ & $\begin{array}{l}\text { Standardized } \\
\text { Coefficients }\end{array}$ & $\begin{array}{c}\text { Error } \\
\text { Variances }\end{array}$ \\
\hline Social Value $\rightarrow$ Emotional Brand Attachment & 6.011 & 0.378 & 0.080 \\
\hline Emotional Value $\rightarrow$ Emotional Brand Attachment & 4.229 & 0.324 & 0.084 \\
\hline Brand Trust $\rightarrow$ Emotional Brand Attachment & 4.141 & 0.194 & 0.045 \\
\hline Ideal Self-Congruity $\rightarrow$ Emotional Brand Attachment & 5.405 & 0.437 & 0.061 \\
\hline Actual Self-Congruity $\rightarrow$ Emotional Brand Attachment & 3.597 & 0.368 & 0.109 \\
\hline $\begin{array}{l}\text { Emotional Brand Attachment } \rightarrow \text { Positive Word of } \\
\text { Mouth }\end{array}$ & 6.015 & 0.441 & 0.082 \\
\hline $\begin{array}{l}\text { Emotional Brand Attachment } \rightarrow \text { Willingness to Pay } \\
\text { Premium Price }\end{array}$ & 6.240 & 0.444 & 0.088 \\
\hline
\end{tabular}

As can be seen in Figure 2 and Table 1, the path coefficients and model fit values for the variables are within acceptable limits and are significant. In this context, it is seen that social value (H1a), emotional value (H1b), brand trust (H2), ideal self congruity (H3) and actual self congruity (H4) have a significant effect on emotional brand attachment. It is also understood that emotional brand attachment has a significant effect on positive word of mouth (H5) and willingness to pay premium price (H6). However, the functional value (H1c) variant does not have a significant effect on emotional brand attachment. In summary, H1a, H1b, H2, H3, H4, H5, and H6 hypotheses have been accepted, while H1c hypothesis has been rejected. 

CONCLUSION

It is seen as one of the basic objectives in order to create brand attachment, to gain market share, and to provide sustainable competitive advantages in rapidly developing competitive markets. Brand attachment constitutes the basis of the marketing activities of the companies and the purpose of the strategic marketing plan. The product features that are similar to the progress of technology push firms to seek different ways to influence consumers. One of the most preferred ways of solving these problems is to appeal to the emotions of the individuals and to create emotional brand attachment in this way. Therefore, it is important to consider the factors affecting the process of creating emotional brand attachment. In this context, the influence of customer value, brand trust, and self- congruity on emotional brand attachment has been investigated. In addition, the effect of emotional brand attachment on the positive word of mouth and willingness to pay premium price, which are effective and costless advertising tools for companies, have also been discussed. The following conclusions have been obtained from the obtained findings:

It has been found that social value is the most effective variable among customer value dimensions on the emotional brand attachment. It overlaps with the activity that the ideal self-congruity has that social value which means the benefit provided by the product to the sense of social sense of the individual. A consistent outcome arises for this age group/research sample, which is considered to pay utmost attention to the individuals in the environment. In this context, it is possible to channel the peer pressure positively, taking into account that the social environment influences the ideas of the people. Also, when the age group's social media usage habits are considered, the use of these channels shall allow people to be directed. In this regard, it is imperative to use emotional values while creating customer value. That is because sports shoes that evoke good emotions in consumers and emotional values reflecting aesthetic and specific style may create emotional attachment to the brand. The lack of effect of functional value to emotional attachment suggests that more than functional features are needed to create emotional attachment. In the light of these results, firms can strengthen social relationship as well as create positive feelings by organizing activities that sports shoes wearers shall enjoy from participating and by being sponsor to various sport activities by establishing fan clubs. In addition, firms can create differences that can affect sports shoes wearers emotionally rather than easy-to-imitate functional features. It can be addressed to the emotions of users by promoting sports shoes on programs that support sports for healthy life or internet sites. In order to create emotional values, they can make aesthetic designs considering the trend colors and can catch a sporty elegance in the shoe design considering the clothes and bag fashion. They can influence the emotions of users with the most trending shoe models.

Brand trust show by the consumers to the brand is also seen to be effective in creating emotional brand attachment. For this reason, fulfillment of the promise by sports shoe brands and showing that the firm is operating in line with the interests of the customer are essential to establish confidence in the consumer. When the customer faces a problem, the sense of trust can be reinforced by searching for a solution way effectively. Thus, customers who think that they get what they pay for shall believe that the brand is honest. Therefore, the brand should exhibit a realistic attitude in its advertisements and avoid the visuals and information that could mislead the consumers. Firms that have achieved it shall be able to achieve long-term profitable results with the sense of trust. They should strive to spread positive experiences in the market to create trust in their relationship with their customers. In this direction, they can use the opinions of people who have used and been satisfied in their promotion activities. They can attach importance to the store atmosphere for trust, which is one of the basic elements of shopping sustainability.

It has been determined that the most effective variable on emotional brand attachment is ideal selfcongruity. It also shows that the most important factor influencing the emotional attachment of students is how the brands which they prefer are perceived by other people. Especially when the age group is taken into consideration, it can be said that the facts of approval, acceptance, and appreciation by the environment are reflected by social consumption products. Development of a brand identity, which is based on the emotions and shall create the ideal perception the individual desire, by the firms which have selected this group as target mass shall provide a great advantage. Actual self- congruity, such as ideal self-congruity, has also been found to have an influence on emotional brand attachment. The tendency of individuals to reflect who they really are with their favorite sport shoes affects the development of emotional attachment to the brand. Therefore, companies that are close to the consumer and who are careful to get to know them shall be able to benefit by developing their marketing strategies in this context. In the light of these conclusions, for ideal self-congruity, firms can influence emotional brand 
Journal of Global Strategic Management | V. 12 | N. 2 | 2018-December| isma.info | 075-086 | DOI: 10.20460/JGSM.2019.270

attachment of consumers by including individuals who attract attentions of the people and to whom they feel admiration in their promotions. They can use the celebrities that the society has shown interest as brand face. In recent times, they can lead individuals to adapt to their ideal self by providing the use of sports shoes in popular programs. They can communicate with people who have a lot of followers in social media and advertise the brand. For actual self, companies can create a stronger self-congruity between brand and user by taking the consumer's thoughts through social media channels or through its staff for the store. In order to learn the real emotions of their users, they can navigate to areas where they can constantly communicate. Within this context, companies can investigate what can be done to meet the expectations by taking part in the environments where the users are intense. They can communicate with users for them to easily communicate criticism about the design that is contrary to the actual self of the individuals to the company.

It clearly shows the importance of establishing strategy by directing to the emotions that emotional brand attachment is influential on the positive word of mouth and willingness to pay premium price which lead to greater profits and competitiveness for the firms. The development of emotional attachment to the brands that sports shoe wearers choose shall ensure that they speak highly about the brand to the people in their environment. This advertisement, which is made without the need for promotions or additional expenditures for the company, may be more effective than the advertisements made with the money with the qualities it has. Besides, the individuals who become devoted users of the brand with their emotional attachment shall be willing to pay a premium price to continue to use their brands. Considering the characteristics of the sample in particular, willingness to pay a premium price presents an important strategic element that should not be overlooked. According to these conclusions, firms should focus on the emotions that have a significant place in the customers' decisions in order to have a more advantageous position. By creating common values, it is necessary for them to make the brand indispensable beyond the logical view. The spread of the reputation of the brands which meet the expectations of the customers and which make them feel good in the market shall make it easier for companies to get closer to customers and exchange ideas. In brief the firm targets and sources must ensure sustainability by using all strategic weapons that may influence emotional attachment in line with market conditions. 


\section{REFERENCES}

Aaker, D.A. (1996). Measuring Brand Equity Across Products and Markets. California Management Review, 38 (3), pp. 102-120.

Abdullah, A.H., Wasiuzzaman, S. and Musa, R. (2015). University Quality and Emotional Attachment of Undergraduate Students in A Private Higher Education in Malaysia: The Mediating Role of Total Experience. International Journal of Social Economics, 42 (7), pp. 644-665.

Abosag, I., Roper, S. and Hind, D. (2012). Examining The Relationship Between Brand Emotion and Brand Extension Among Supporters of Professional Football Clubs. European Journal of Marketing, 46(9), pp. 1233-1251.

Abubakar, B. and Mavondo, F. (2014). Tourism Destinations: Antecedents to Customer Satisfaction and Positive Word-Of-Mouth. Journal of Hospitality Marketing \& Management, 23, pp. 833-864.

Asshidin, N. H. N., Abidin, N. and Borhan, H. B. (2016). Perceived Quality and Emotional Value that Influence Consumer's Purchase Intention towards American and Local Products. Procedia Economics and Finance, 35, pp. 639-643.

Assiouras, I., Liapati, G., Kouletsis, G., and Koniordos, M. (2015). The Impact of Brand Authenticity on Brand Attachment in The Food İndustry. British Food Journal, 117(2), pp.538-552.

Aydeniz, N., and Yüksel, B. (2007). Hizmet İşletmelerinde Pazar Yönlü Değer Yaratma: Finansal Performansa Etki Boyutu. Elektronik Sosyal Bilimler Dergisi, 6(20), pp. 95-111.

Bagozzi, R.P., Gopinath, M. and Nyer, P.U. (1999). The Role of Emotions in Marketing. Journal of The Academy of Marketing Science, 27(2), pp. 184-206.

Barreda, A., Nusair, K., Okumus, F. and Bilgihan, A. (2013). Developing A Brand Structure Pyramid Model for Travel-Related Online Social Networks. Tourism Review, 68 (4), pp. 49-70.

Berry, L.L. (2000). Cultivating Service Brand Equity. Journal of the Academy of Marketing Science, 28 (1), pp. 128-137.

Burke, P.J. and Stets, J. E. (1999). Trust and Commitment through Self-Verification. Social Psychology Quarterly, 62 (4), pp. 347-360.

Casidy, R. and Wymer, W. (2016). A Risk Worth Taking: Perceived Risk As Moderator of Satisfaction, Loyalty, and Willingness-to-Pay Premium Price. Journal of Retailing and Consumer Services, 32, pp. 189-197.

Cepeda-Carrion, I., Martelo-Landroguez, S., Leal-Rodríguez, A.L. and Leal Millána, A. (2016). Critical Processes of Knowledge Management: An Approach Toward The Creation of Customer Value. European Research on Management and Business Economics, 23 (1), pp. 1-7.

Chaudhuri, A. and Holbrook, M.B. (2001). The Chain of Effects from Brand Trust and Brand Affect to Brand Performance: The Role of Brand Loyalty. Journal of Marketing, 65(2), pp. 81-93.

Chinomona, R. (2013). The Influence of Brand Experience on Brand Satisfaction, Trust And Attachment in South Africa. The International Business \& Economics Research Journal (Online), 12(10), pp. 13031316.

Chinomona, R. (2016). Brand Communication, Brand Image and Brand Trust As Antecedents of Brand Loyalty in Gauteng Province of South Africa. African Journal of Economic And Management Studies, 7 (1), pp. $124-139$.

Çokluk, Ö., Şekercioğlu, G. and Büyüköztürk, Ş. (2010). Sosyal Bilimler İçin Çok Değişkenli İstatistik. Ankara: Pegem Yayınları.

Das, G. (2014). Impacts of Retail Brand Personality and Self-Congruity on Store Loyalty: The Moderating Role of Gender. Journal of Retailing and Consumer Services, 21, pp. 130-138.

Delgado-Ballester, E., Munuera-Aleman, J. L. and Yague-Guillen, M. J. (2003). Development and Validation of A Brand Trust Scale. International Journal of Market Research, 45(1), pp. 1-58. 
Journal of Global Strategic Management | V. 12 | N. 2 | 2018-December| isma.info | 075-086 | DOI: 10.20460/JGSM.2019.270 Hazan, C. and Shaver, P. R. (1994). Attachment As An Organizational Framework for Research on Close Relationships. Psychological Inquiry, 5(1), pp. 1-22.

Heath, R., Brandt, D., And Nairn, A. (2006). Brand Relationships: Strengthened By Emotion, Weakened By Attention. Journal of Advertising Research, 46(4), pp. 410-419.

Hemetsberger, A., Kittinger-Rosanelli, C.M.T. and Friedmann, S. (2009). 'Bye Bye Love'-Why Devoted Consumers Break Up With Their Brands. Advances in Consumer Research, 36, pp. 430-437.

Hudson, S., Roth, M.S., Madden, T.J. and Hudson, R. (2015). The Effects of Social Media on Emotions, Brand Relationship Quality, and Word of Mouth: An Empirical Study of Music Festival Attendees. Tourism Management, 47, pp. 68-76.

Hur, W.M., Yoo, J.J. and Chung, T,L. (2012). The Consumption Values and Consumer Innovativeness on Convergence Products. Industrial Management \& Data Systems, 112 (5), pp. 688-706.

Hung, H,Y. (2014). Attachment, Identification, and Loyalty: Examining Mediating Mechanisms Across Brand and Brand Community Contexts. Journal of Brand Management, 21 (7-8), pp. 594-614.

Hwang, J. and Kandampully, J. (2012). The Role of Emotional Aspects in Younger Consumer-Brand Relationships. Journal of Product \& Brand Management, 21 (2), pp. 98-108.

Kim, H,W., Koh, J. and Lee, H.L. (2009). Investgating the Intention of Purchasing Digital Items in Virtual Communities. Pasific Asian Conference on information Systems (PACIS), 18.

Kim, H. W., Gupta, S. and Koh, J. (2011). Investigating The Intention to Purchase Digital Items in Social Networking Communities: A Customer Value Perspective. Information \& Management, 48(6), pp. 228234.

Kim, J., and Joung, H.M. (2016). Psychological Underpinnings of Luxury Brand Goods Repurchase İntentions: Brand-Self Congruity, Emotional Attachment, and Perceived Level of Investment Made. Journal of Global Scholars of Marketing Science, 26 (3), pp.284-299.

Kowalczyk, C.M, And Pounders, K.R. (2016). Transforming Celebrities Through Social Media: The Role of Authenticity and Emotional Attachment. Journal of Product \& Brand Management, 25 (4), pp.345-356.

Lee, Y. K., Back, K. J. and Kim, J. Y. (2009). Family Restaurant Brand Personality and Its Impact on Customer's Emotion, Satisfaction, and Brand Loyalty. Journal of Hospitality \& Tourism Research, 33(3), pp. 305-328.

Levy, S. and Hino, H. (2016). Emotional Brand Attachment: A Factor in Customer-Bank Relationships. International Journal of Bank Marketing, 34(2), pp. 136-150.

Li, N., Robson, A. and Coates, N. (2013). Chinese Consumers' Purchasing: Impact of Value and Affect. Journal of Fashion Marketing and Management: An International Journal, 17(4), pp. 486-508.

Lien, C. H. and Cao, Y. (2014). Examining Wechat Users' Motivations, Trust, Attitudes, and Positive Word-of-Mouth: Evidence From China. Computers İn Human Behavior, 41, pp. 104-111.

Lin, N. H., Tseng, W. C., Hung, Y. C. and Yen, D. C. (2009). Making Customer Relationship Management Work: Evidence From The Banking Industry in Taiwan. The Service Industries Journal, 29(9), 1183-1197.

Malär,L., Krohmer, H., Hoyer, W.D. and Nyffenegger, B. (2011). Emotional Brand Attachment and Brand Personality: The Relative Importance of The Actual and The Ideal Self. Journal of Marketing, 75 (4), pp. 35-52.

Martelo Landroguez, S., Barroso Castro, C. and Cepeda-Carrión, G. (2011). Creating Dynamic Capabilities to Increase Customer Value. Management Decision, 49(7), pp. 1141-1159.

Naylor, G. and Kleiser, S.B. (2000). Negative Versus Positive Word-of- Mouth: An Exception to The Rule. Journal of Consumer Satisfaction, Dissatisfaction and Complaining Behavior, 13, pp. 26-36.

Ishikawa, K. (2013). Brand Dynamics: The Effects of Brand Personality and Brand Experience on Emotional Brand Attachmnet. (Published Doctoral Thesis). Southern Illinois University Carbondale. 
Journal of Global Strategic Management | V. 12 | N. 2 | 2018-December| isma.info | 075-086 | DOI: 10.20460/JGSM.2019.270

Jawahar, P. D. and Maheswari, R. (2009). Service Perception: Emotional Attachment As A Mediator of The Relationship Between Service Performance and Emotional Brand. IUP Journal of Marketing Management, 8(2), pp.7-22.

Jiménez, F. R. and Voss, K. E. (2014). An Alternative Approach to The Measurement of Emotional Attachment. Psychology \& Marketing, 31(5), pp. 360-370.

Oliver-Skuse, T. (2015). Emotion and Value, edited by Roeser, Sabine and Todd, Cain. Australasian Journal of Philosophy, 93 (4), pp. 839-840.

Orth, U. R., Limon, Y. and Rose, G. (2010). Store-Evoked Affect, Personalities, and Consumer Emotional Attachments to Brands. Journal of Business Research, 63(11), pp. 1202-1208.

Park, C, W., MacInnis, D.J., Priester, J., Eisingerich, A.B. and Iacobucci, D. (2010). Brand Attachment and Brand Attitude Strength: Conceptual and Empirical Differentiation of Two Critical Brand Equity Drivers. Journal of Marketing, 74 (6), pp. 1-17.

Park, M., and Yoo, J. (2016). E-Mass Customization: Effects of Self-Congruity and Functional Congruity on Consumer Responses. Social Behavior and Personality: An International Journal, 44(8), pp. 1379-1394.

Pawle, J. and Cooper, P. (2006), Measuring Emotion-Lovemarks, The Future Beyond Brands. Journal of Advertising Research, 46(1), pp. 38-48.

Reimann, M., Castaño, R., Zaichkowsky, J. and Bechara, A. (2012). How We Relate to Brands: Psychological and Neurophysiological Insights into Consumer-Brand Relationships. Journal of Consumer Psychology 22 (1), pp. 128-142.

Ruth, J. A. (2001). Promoting A Brand's Emotion Benefits: The Influence of Emotion Categorization Processes on Consumer Evaluations. Journal of Consumer Psychology, 11(2), pp. 99-113.

Sağlam, B.Ç. and Sağlam, M. (2016). Marka Güveni ve Marka Bağlılığının Satın Alma Niyeti Üzerine Etkisi: Akıllı Telefon Pazarında Bir Araştırma. İşletme \& Sosyal Bilimler Araştırmaları Dergisi, 5(5), pp. 34-43.

Sicilia, M., Delgado-Ballester, E. and Palazon, M. (2016). The Need to Belong and Self-Disclosure in Positive Word-of-Mouth Behaviors: The Moderating Effect of Self- Brand Connection. Journal of Consumer Behavior, 15 (1), pp. 60-71.

Sirgy, M. J. (1982). Self-Concept in Consumer Behavior: A Critical Review. Journal of Consumer Research, 9(3), pp. 287-300.

Sirgy, M.J., And Johar, J.S. (1999). Toward An Integrated Model of Self- Congruity and Functional Congruity. European Advances in Consumer Research, 4, pp. 252-256.

Sirgy, M. J., Grewal, D. and Mangleburg, T. (2000). Retail Environment, Self-Congruity, and Retail Patronage: An Integrative Model and A Research Agenda. Journal of Business Research, 49(2), pp. 127138.

Theng So, J., Grant Parsons, A. and Yap, S. F. (2013). Corporate Branding, Emotional Attachment and Brand Loyalty: The Case Of Luxury Fashion Branding. Journal of Fashion Marketing and Management: An International Journal, 17(4), 403-423.

Sweeney, J. C. and Soutar, G. N. (2001). Consumer Perceived Value: The Development of A Multiple Item Scale. Journal of Retailing, 77(2), pp. 203-220.

Thanasuta, K. and Metharom, P. (2015). Influencing The Willingness to Pay For Private Labels: The Role of Branding. Asia-Pacific Journal of Business Administration, 7(3), pp. 197-215.

Thomson, M., Macinnis, D.J. and Park, C.W. (2005). The Ties That Bind: Measuring The Strength of Consumers' Emotional Attachments to Brands. Journal of Consumer Psychology, 15(1), pp. 77-91.

Todd, C. (2014). Emotion and Value. Philosophy Compass, 9(10), 702-712.

Vlachos, P. A., Theotokis, A., Pramatari, K. and Vrechopoulos, A. (2010). Consumer-Retailer Emotional Attachment: Some Antecedents and The Moderating Role of Attachment Anxiety. European Journal of Marketing, 44(9/10), pp. 1478-1499. 
Journal of Global Strategic Management | V. 12 | N. 2 | 2018-December| isma.info | 075-086 | DOI: 10.20460/JGSM.2019.270 Wu, T., Lu, Y., Gong, X. and Gupta, S. (2017). A Study of Active Usage of Mobile Instant Messaging Application: An Attachment Theory Perspective. Information Development, 33(2), pp. 153-168.

Yusof, J.M. and Ariffin, S. (2016). The Influence of Self-Congruity, Functional Image, and Emotional Attachment on Loyalty. Procedia Economics and Finance, 37, pp. 350-357. 